HOWARD JOHNSON

\title{
FROM PARIAH TO PATRIOT: THE POSTHUMOUS CAREER OF GEORGE WILLIAM GORDON
}

On October 23, 1865, George William Gordon, a wealthy Colored merchantlandowner and member of Jamaica's House of Assembly, was hanged after a hastily convened court martial found him guilty of complicity in a conspiracy which led to the Morant Bay "Rebellion" earlier that month. One hundred years later, Gordon and his alleged co-conspirator Paul Bogle were commemorated as patriots and declared national heroes. Gordon's commitment to institutionalized memory by the Jamaican government was one aspect of a process which often accompanied decolonization in the Anglophone Caribbean - the search for the roots of nationalism and the replacement of metropolitan heroes with local ones. In Barbados, for example, ten persons were named as national heroes in 1998. In that same year, the government of St. Lucia designated the first Monday in August every year as National Heroes Day. In 2002, St. Vincent and the Grenadines announced their first national hero (Johnson 1999, 2004). The rehabilitation of Gordon's reputation was, however, more than a government initiative. It represented the culmination of a reappraisal (involving the "articulate" classes) which had taken place in the island's newspapers, in locally produced historical works, magazines, and literary works since Gordon's death. In examining Gordon's posthumous journey from pariah to patriot, this article traces the career of a reputation and with it the social, political, and cultural contexts which, over time, shaped and transformed Jamaican collective remembering.

Gordon was born a slave, the son of a slave woman and a Scottish planting attorney and proprietor who freed him. He eventually became a successful dealer in produce which enabled him to acquire several properties throughout the island. In 1844 he was elected to the House of Assembly where he served until 1849. Little in his early political career suggested that he would later develop as a radical politician with a special interest in the problems of the laboring classes. Gordon's emergence, by the early $1860 \mathrm{~s}$, as the spokesman for the black poor is partly explained by his religious experience of that period. Originally a member of the United Presbyterian Mission in Jamaica, he later

New West Indian Guide / Nieuwe West-Indische Gids vol. 81 no. 3 \& 4 (2007):197-218 
turned to the Congregationalists and the Baptists for a more spiritually satisfying experience (Green 1976:386-87). In 1861, during the Great Revival, he joined the Native Baptists and later opened mission stations at Bath and Spring Gardens in St. Thomas-in-the-East, where he acted as a lay preacher. Gordon's association with the Native Baptists (whose membership was historically Black) was unusual for a colored person of his wealth and social status and isolated him from members of his own class. It led, however, to an increased knowledge of and interest in the problems of the black laboring classes.

Gordon's religious work in St. Thomas-in-the-East, where he owned the Rhine Estate, was soon combined with political activities. With the help of Paul Bogle, a Native Baptist preacher with his own chapel in Stony Gut, Gordon created a base of political support for himself in that area. Both men collaborated to increase the black vote despite the restrictions of the 1859 Franchise Bill. The effectiveness of Bogle's political organization and electoral campaigning was demonstrated in March 1863, when Gordon was elected to the House after an earlier defeat in February of the previous year.

In the House, Gordon became the most consistent spokesman for the laboring classes. In the legislative session of 1864-1865, for example, he called for tax relief for the poor and vigorously opposed a bill in which the administration sought to deal with the problem of praedial larceny by inflicting corporal punishment on convicted offenders. Gordon's open sympathy with the black poor and his emotionally charged oratorical style did much to alienate him from his colleagues in the House of Assembly. He also became the leading critic of Governor Edward John Eyre's administration. Gordon's main criticisms of Eyre's administration were usually directed at what he regarded as the lieutenant-governor's unsympathetic and complacent response to the problems of the poor. In 1864, he expressed his frustration with the failure of the colonial authorities to ameliorate social and economic conditions in the colony in terms which were later cited as evidence that he had long plotted insurrection: "If we are to be governed by such a Governor much longer, the people will have to fly to arms and become self-governing." These attacks led Eyre to regard Gordon as his chief political opponent and the island's leading troublemaker. ${ }^{1}$

The outbreak of disturbances in Morant Bay and its environs in which Bogle was involved provided Eyre with an opportunity for reprisals against Gordon whom he regarded as primarily responsible for the riots. After visiting the scene of the riots, Eyre reported to the colonial secretary: "I found everywhere the most unmistakable evidence that Mr. Geo W. Gordon, a coloured member of the House of Assembly, had not only been mixed up in the matter, but was himself, through his own representation and seditious language

1. For a discussion of historical writing on Gordon, Bogle, Eyre and the Morant Bay Rebellion see Higman 1999:208-15. 
addressed to the ignorant black people, the chief cause and origin of the whole rebellion" (Hart 1972:105). Gordon, who was ill in bed at the time of the riot, was arrested on Eyre's orders and taken to Morant Bay where martial law was in force. He was tried, in a perfunctory court martial on two counts: "high treason and sedition" and "having complicity with certain persons in the insurrection at Morant Bay on the 11th October 1865," and sentenced to death. The Royal Commission of Enquiry of 1866 into the rebellion found no evidence that Gordon was involved in its outbreak (Hart 1972:144).

In the aftermath of the Morant Bay disturbances, the colonial administration's reprisals against the rioters (real and suspected) were swift and brutal. Martial law was declared in the county of Surrey, with the exception of Kingston, naval forces were dispatched to Morant Bay, and troops, the colonial militia, and Maroons were mobilized to suppress the rebellion. According to official estimates, 354 persons were executed after a summary court martial, 85 were shot by troops without any trial, 600 persons (including women) were flogged, and 1,000 buildings destroyed. The brutality of the repression, intended to induce terror in the black population, reflected the exaggerated racial fears of the Whites and Browns. These fears were reinforced by the memories of two events, the slave revolt of the 1790s in Saint Domingue and the Indian Mutiny of 1857 which some of the soldiers, involved in the suppression of the riots, had experienced (Semmel 1962:4750; Green 1976:389; Holt 1992:302).

In the atmosphere of crisis which surrounded the Morant Bay riots, Eyre recognized the opportunity for introducing constitutional change for which he had long campaigned. His primary technique for winning support for change was to play on the racial and class fears of the white and brown assembly men, many of whom anticipated that the continued existence of representative government would eventually result in black control of an elective Assembly. In December 1865, the Assembly voted to surrender its legislative powers to the Crown. In the following year, the British government introduced Crown Colony government which replaced the Assembly with a legislature of nominated members and an official majority (Holt 1992:303). As Roy Augier $(1966: 33,38)$ has observed, "The constitution of 1866 gave the British political authority in an autocratic form." This autocratic power, the Colonial Office maintained, would guarantee impartial government and protect the interests of the poor and ignorant black majority.

In the years after Gordon's death, his detractors and defenders offered competing narratives of his life and involvement in the Morant Bay Rebellion. Immediately following the riots, the brown and white elite expressed fervent support for Eyre's brutal suppression which, they believed, had averted another Haiti. Their racial and class fears were reflected in the addresses presented to Eyre before he left the island in 1866. An address from the "owners and representatives of property in the mountain districts of the parishes of 
Port Royal and St. David" stated, "We believe the rebellion had not only for its object the overthrow of constituted authority, but also the massacre of the white and coloured people who owned and represented property, and then its division among the lower orders; and we rejoice to be able to bear testimony, that your Excellency was anything but "unequal to the occasion."'2 A valedictory editorial in the Gleaner and De Cordova's Advertising Sheet was equally effusive in Eyre's praise: "In going from these shores, Mr. Eyre carries with him the conviction that the intelligence, the wealth and respectability of all creeds and complexions in Jamaica have more than once given him tokens of gratitude for saving the island from destruction, and its inhabitants from scenes worse than death itself." 3 By contrast, Gordon's culpability was widely accepted and condemned despite the findings of the 1866 commission exonerating him. In November 1865 the Gleaner advertised a "De Cordova's History of the Rebellion of 1865, in Jamaica" whose contents included 'One of George Gordon's Rebel 'Proclamations,' from the original manuscript in the handwriting of George W. Gordon." In that same month, the photographic gallery of Duperley Brothers offered for sale portraits of "the Arch-Traitor G.W. Gordon."5

The establishment perspective on Gordon as a traitor who precipitated the Rebellion by his political agitation persisted into the early twentieth century and quickly became historical orthodoxy. As Ansell Hart pointed out, the Reverend W.J. Gardner, Gordon's erstwhile friend, demonstrated an ambivalence on the subject in A History of Jamaica when he quoted from the commission's report: "it appears exceedingly probable that Mr. Gordon, by his words and writings, produced a material effect on the minds of Bogle and his followers, and did much to produce that state of excitement and discontent in different parts of the island which rendered the spread of the insurrection exceedingly probable" (Gardner 1971:489; Hart 1972:134). Laurence R. Fyfe and A.C. Sinclair's "Outlines of the History of Jamaica," published in 1883, reflected the elite view of Gordon's role in the rebellion: "Mr. George William Gordon, a member of the House of Assembly, was tried by court-martial and hanged for complicity in the disturbances; and of other ringleaders amongst the insurgents some incurred the penalty of death and others were sentenced to various terms of imprisonment." Although Fyfe and Sinclair (1883:38) mentioned the Royal Commission and its findings, they failed to note that it had exonerated Gordon. In the 1896 edition of the Handbook of Jamaica, a reference to the Morant Bay Rebellion described George William Gordon as "the principal agitator ... who was mainly responsible" (Musson \& Roxburgh

2. Gleaner and De Cordova's Advertising Sheet, June 28, 1866.

3. Gleaner, July 24, 1866.

4. Gleaner, November 10, 1865.

5. Gleaner, November 20, 1865. 
1896:46). Frank Cundall (1915:245) perpetuated this view of Gordon in his Historic Jamaica with his description of him as a "ringleader."

The unwavering perception of Gordon as a traitor who had brought on the rebellion by his intemperate speeches and his political agitation is best explained by the fact that the brown and white propertied classes were convinced that the black lower classes remained susceptible to what they viewed as demagoguery. As a result, they lived in fear of the recurrence of a breakdown in law and order. This was a view shared by successive colonial administrators and Colonial Office officials who regarded "black and coloured peoples" as easily excitable and with little self-control (Will 1970:51-52). The fears of the effect of political agitation increased in the early $1880 \mathrm{~s}$ when Blacks became involved in the campaign (conducted by the Jamaica Association and newspaper editors) for constitutional reform (Lumsden 1998:114). In 1882 the political campaign revived memories of Gordon, his efforts to extend black political participation and his fate. As the editor of the Westmoreland Telegraph observed,

\begin{abstract}
If what the Spiritualists tell us is true, that the spirit of dead men are still moving among us frequenting their old haunts and taking interest in mundane affairs, the shade of George William Gordon must have been surprised and delighted to see George Henderson taking up the mantle which he had to drop on his last fatal visit to Head Quarters House, and boldly declaring his opinion that even the 440,000 black people of Jamaica ought to have their share in the legislation of the country whether we have Crown or Representative Institutions. History they say is always repeating itself, but we hope Crown Government will not serve George Henderson and James Gall in the same way as Representative Government served George William Gordon and Sydney [sic] Levien. ${ }^{6}$
\end{abstract}

With the extension of the franchise in 1885 , Gordon was seen as a precursor of a new-style politician who was prepared to make his appeal to newly enfranchised black voters on the basis of race and class concerns. J.V. Calder, a wealthy penkeeper, competing with Alexander Dixon, a black shopkeeper, for a seat in the Legislative Council, complained in 1899 about the nature of Dixon's appeal to the ten-shilling voter:

He gained the support of the 10 s voter by misrepresenting me and telling him he would take off the house tax, and put such a tax on the "big man's" land that they would have to forfeit it to the Crown, and the people would then get plenty of cheap land.

6. Reprinted in Gleaner, December 28, 1886. George Henderson and James Gall were both journalists. Henderson had also served in the House of Assembly. For Sidney Levien see later discussion. 
A very similar cry was one of the causes of the rebellion of 1865 , and it is a dangerous one to trade on. Our peasantry are law-abiding and wellbehaved, but their civil passions soon get beyond control if their ignorance is traded on by mischeivous [sic] demagogues. Mr. Dixon was probably "under the care of his parents" in ' 65 when "poor people" had G.W. Gordon and Paul Bogle as their champions. ${ }^{7}$

In the first decade of the twentieth century, George William Gordon continued to be associated in the minds of members of the propertied classes with contemporary politicians who, in their view, stirred up trouble and threatened the social and economic order. In May 1909, for example, Louis Lindo, in a thinly disguised allusion to the political campaigning of Paul Bogle and Gordon, warned of the long-term consequences of the activities of the political agitator:

The Political Agitator without character or intelligence to lead and direct is a dangerous man; hitherto he has worked irreparable injury and injustice. If in the future we are again to enjoy a free Legislative Assembly, the right of self-government, we must rely on the intelligence and respectability of the Island, not on the vulgar, ignorant, self-seeking men who have hitherto misled the humble class. ${ }^{8}$

Given these views, it is not surprising that Lindo should have earlier, in 1906, concluded that "Mr. Gordon was no true Patriot," and went on to state "that there was more malicious spirit than patriotism in the conduct of Mr. Gordon." By contrast, Lindo expressed the opinion that "Governor Eyre, who has been unmercifully blackened, in certain quarters, was the more patriotic man." 9

Gordon's public reputation in the early twentieth century was shaped by the slanderous stories, which had circulated since his death, impugning his character. These alleged character traits had been mentioned by Eyre in a dispatch to the colonial secretary in January 1866 and later in his testimony before the Royal Commission: "he was simply a hypocrite, using the garb

7. Letter by J.V. Calder, dated February 27, 1899, in the Daily Gleaner, March 1, 1899. Calder purchased the Worthy Park estate later that year. For the importance of the issue of race and color in this election campaign see "The Election Campaign in St. Elizabeth," Daily Gleaner, January 21, 1899. As Charles E. Isaacs, one of Calder's supporters had warned, "It was a dangerous thing for people to say that having sent a white and a brown man they must now send a black man to the Council. They should beware!"

8. See "The Essential Legislature," Jamaica Times, May 22, 1909. Louis Lindo had operated a hotel and livery business in Mandeville in the opening years of the twentieth century but resided in Kingston in 1909.

9. Letter by Louis Lindo, dated December 13, 1906, Jamaica Times, December 22, 1906. 
of religion to conceal his villainy ... It is also well known out here that $\mathrm{Mr}$. Gordon was almost universally regarded as a bad man in every sense of the world. Reputed to be grossly immoral and an adulterer, a liar swindler, dishonest, cruel, vindictive and a hypocrite" (Hart 1972:102). In 1906, George Solomon, a wealthy Jewish merchant-planter and a former member of the House of Assembly, wrote of Gordon as a man who had assaulted his own father and exploited the workers on his properties, refusing to pay them for work done. As he observed: "when such a character is put forth as a 'Christian Hero,' and when he is proved to be a hypocrite of hypocrites the facts should not be concealed." 10 To this list of character flaws, Louis Lindo added that of cowardice, in a letter to the Jamaica Times in that same year: "he left others to fire the torch he had kindled, by which means he hoped to have been thought innocent." 11

In his newspaper commentaries and his novel Revenge of 1919, H.G. de Lisser, the off-white editor of the Daily Gleaner, reflecting contemporary elite apprehension of political agitation, portrayed George William Gordon as a man of words, with unintended yet positive long-term consequences. Unlike many members of his own class, de Lisser acknowledged that the Morant Bay disturbances were not solely the result of Gordon's political agitation. In August 1906, in an editorial obituary of Charles L. Campbell, who as editor of the Budget had been at the center of the antigovernment agitation in the early 1860s, de Lisser observed:

\footnotetext{
Then came the rioting at Morant Bay, a demonstration due to many circumstances, and not alone, as some uninformed people have thought to the ill-advised, ill-balanced rhetoric of George William Gordon. Gordon's character is one that we cannot profess to like, and his methods were foolish in the extreme; yet he protested against real wrongs, and he and the other agitators of the time were a living proof that a change of conditions was needed. ${ }^{12}$
}

By 1913, de Lisser's assessment of Gordon's role in the 1865 disturbances was more developed. Writing under the pseudonym of "The Observer," he suggested that the debate over those events had subsided and that Gordon and Eyre were already passing from the collective memory: "Historians, of course, will always remember Gordon, and educated men will know something about him and about the Governor who hanged him. But to the genera-

10. Letter by George Solomon, undated, Daily Gleaner, October 30, 1906.

11. Letter by Louis Lindo, dated November 8, 1906, Jamaica Times, November 17, 1906.

12. See editorial "In Memorium [sic]," Daily Gleaner, August 13, 1906. De Lisser served as the editor of the newspaper from 1904 until his death forty years later. 
tion of fifty years hence Gordon and Eyre will not be much better known than are Cudjoe and Sir William Trelawny to-day ... Who speaks of Gordon and Eyre now?" De Lisser's view that Gordon's actions were not disinterested was clearly shaped by contemporary Jamaican politics:

Do we hold, then, the old opinion entertained by some that Gordon was a good and holy man, wantonly done to death? Our answer is that George William Gordon's life has never been truly written, and that, if it were truly written, it would probably be found that Gordon mixed up a great deal of personal feeing with his denunciation of public wrongs. He was not a good man. Governor Eyre was not a good man. Gordon certainly protested against wrongs that ought not to have existed, but his protest was not impersonal: we fear that all the time he was thinking more of George William Gordon than of the people. This is the case with far too many agitators and leaders, and Gordon was no exception to this class [emphasis added].

De Lisser contended that the Morant Bay Rebellion, which Gordon had unwittingly precipitated, had resulted in the introduction of a benevolent government:

We do not waste useless tears over the uprising; there had to be a great moral earthquake before betterment and change could be hoped for in this island: there had to be a crisis. It was that crisis that put an end to the old order and ushered in the new. Gordon did serve his country by his death, but he never intended to die, he never anticipated death, he played with fire without clearly realising that it might burn, and that he himself might be consumed in the conflagration. ${ }^{13}$

De Lisser's fictional portrait of Gordon in his 1919 novel, Revenge, followed closely the views he had expressed in his political commentaries. Gordon was depicted as a man who had, by his political agitation, provoked events which he could not control:

For Gordon playing always for position and power, hungry for applause and hating every opponent with a bitter hate, had never clearly set before his mental vision the possible consequences of his agitation. He was deliberately stirring up the passions of an emotional people in the hope of intimidating the Government; he trusted that he would always be able to control men like Paul Bogle. Which proved he did not really know Paul Bogle. (de Lisser 1919:24)

13. "George William Gordon \& 1865," Daily Gleaner, February 19, 1913. For an extended discussion of the political agitator in early twentieth-century Jamaican politics see de Lisser 1913:149-52. 
In the years after the Morant Bay Rebellion, Gordon's defenders provided a counternarrative (to that advanced by the brown and white elite) by maintaining his innocence and portraying him as a martyr and hero. It is significant that his earliest defenders expressed their views outside Jamaica. In the aftermath of the rebellion, the colonial administration had directed its repressive measures at the laboring classes in St. Thomas-in-the-East and its brown and white critics. Sidney L. Levien, a Montego-Bay-based Jewish journalist, who had gained "considerable notoriety by reason of his editorial attacks on Governor Eyre," was arrested and taken in a sloop of war to Morant Bay. ${ }^{14}$ Both Levien and another white critic, Dr. Robert Bruce of Vere, narrowly escaped Gordon's fate (Jacobs 1973:103). The effect of these actions was to stifle dissenting political opinion from any quarter. As H.G. de Lisser remembered in 1913: "It was the custom in this country not long ago, whenever any one was busy agitating for something or other, to say to that person: 'Remember Gordon!' The warning conveyed a threat: 'They hanged Gordon, take care they do not hang you."'15

As early as January 1866, the Reverend Henry Clarke, the rector of the Anglican Church in Savanna-La-Mar, in a letter to the secretary of the AntiSlavery Society in England, insisted that Gordon was innocent and would be remembered as a martyr: "G.W. Gordon is at this moment speaking more loudly, more persistently, more effectively for the people of Jamaica than ever he did in his life time, and the time is not far distant when amid the grateful tears of a free and prosperous people a glorious monument shall be erected over his grave inscribed to him as the self-sacrificing martyr whose blood sealed the Magna Carta of the black man's liberties." ${ }^{16}$ Clarke recognized that he was expressing a minority opinion for most members of his congregation had earlier signed an address supporting Governor Eyre's actions (Walvin 1994:48).

Within three years of Gordon's death, two ministers of religion, living in England, asserted Gordon's innocence. In 1867, the Reverend Duncan Fletcher, who had served as a missionary with the London Missionary Society on the island and knew Gordon, published a sympathetic account of

14. See the obituary of Sidney Levien, "The Death of Mr. S.L. Levien," Daily Gleaner, September 27, 1895.

15. "George William Gordon \& 1865," Daily Gleaner, February 19, 1913. The fear of the consequences of political agitation was reflected in a letter by "Portlander," undated, Jamaica Times, May 1, 1909. It was prompted by the establishment of the National Club, in March of that year, which had then launched a political campaign for the removal of Governor Sydney Olivier from Jamaica. "Portlander" had observed: "It was through political agitation and inflammatory speeches that the so-called Rebellion in St. Thomasin-ye-East in 1865 occurred, and those who are acquainted with the history of it knows [sic] how awful were the consequences."

16. See Edith Clarke, "Black Dignity," Daily Gleaner, October 16, 1965. 
his life (Fletcher 1867). ${ }^{17}$ The Gleaner's editorial response to this publication demonstrates the difficulty of defending Gordon in Jamaica's "respectable" society at this time:

It will be remembered that Mr. Fletcher was a political agitator, and, in concert with Gordon, wrought an amount of mischief among the people which at one time, it was feared would, if persisted in, culminate in negro riots against those in authority. Fortunately, Mr. Fletcher left the country before the seeds took root, which he, in concert with George W. Gordon scattered to the annoyance of his brother ministers and all right-thinking people in Jamaica. ${ }^{18}$

In 1868, C.H. Spurgeon, a British Baptist minister and England's best-known preacher, who knew Gordon by reputation, described him as "a Christian hero, a soldier of liberty, and a defender of the right" and predicted, "His name and story will forever be intertwisted with the substance of Jamaica's history, and the day will come when statues will be erected to his memory and their unveiling sanctioned by the presence of the highest authorities of the island." 19

In Jamaica, the public defense of Gordon's political career and condemnation of the manner of his death began in the closing decades of the nineteenth century in a period of constitutional change. In 1883, for example, at the time of agitation for constitutional reform, the editor of the Falmouth Gazette stated, "George William Gordon, for trying to uproot the wrongs of Government in 1865 , was illegally arrested, illegally tried by an illegally constituted Military Court Martial, and murdered, despite his cries for justice." ${ }^{20}$ By 1896, R.E. Clarke, a minister of religion, predicted "the day may come when Gordon's statue will be deemed a worthy addition to the city of Kingston." ${ }^{21}$ However, a proposal that a statue of Gordon should be erected by subscription "was received with horror" in that same year. ${ }^{22}$

In 1899, W.P. Livingstone, the English editor of the Daily Gleaner undertook a revaluation of the circumstances of the Morant Bay Rebellion and Gordon's role in it. He concluded that Gordon was a political agitator who hoped to force "a radical change in the conditions of Government" rather than a conspirator in rebellion. Livingstone pointed out that in the wake of

17. For a discussion of Fletcher's relationship with Gordon see Stewart 1992:163-64.

18. Gleaner and De Cordova's Advertising Sheet, April 1, 1867.

19. Quoted in a letter by R.E. Clarke, dated July 3, 1896, Daily Gleaner, July 6, 1896.

20. See editorial "Crown Government in Jamaica," reprinted in Daily Gleaner, January 30,1883 .

21. Letter by R.E. Clarke, dated July 3, 1896, Daily Gleaner, July 6, 1896.

22. See "St. Andrews Parochial Board," Daily Gleaner, October 3, 1896. 
the disturbances, the colonial government used Gordon as a scapegoat for a situation that it had created:

\begin{abstract}
It was during this period of palpitating fear that the authorities offered up Gordon's life on the scene of disorder, a sacrifice to a condition of things which they themselves had created. For it was the Government which was primarily to blame for the tragedy. It had refused to accept the responsibility of educating the people; for a whole generation it had done nothing to improve their ethical and industrial efficiency. It had proved incapable of governing the country aright; it had reduced it to a state of bankruptcy and ruin. It had allowed race-prejudice, private animosities, and class oppression to prevail. It had defied the spirit of discontent until in one quarter it issued in a quarrel and a riot. (Livingstone 1899:76)
\end{abstract}

With greater attention directed to policies benefiting the laboring classes, under Crown Colony government, contemporary observers increasingly appreciated the forward-looking measures which Gordon had earlier proposed. In 1899, for example, Reverend Henry Clarke, by then an elected member of the Legislative Council, claimed that the education grant of that year "was the first effort he had ever known ... to elevate the people and make them a moral and civilised community." He expressed the opinion that, except for Gordon, "the Christian Ministers" had done everything "for the progress and uplifting of the country": "George William Gordon spoke for the progress of the people in the House of Assembly, and they all know what reward was accorded him." 23 In March of the following year, G.F. Judah, a prominent citizen of Spanish Town and an amateur historian, noted that Gordon's reform proposals had anticipated those introduced by Sir John Peter Grant under Crown Colony Government: "All the measures in favour of the masses in Jamaica, George William Gordon advocated and pressed for and for which he was hanged, were the measures initiated and carried through by the first Governor Administrator, and they have formed the basis since of all legislation." 24

In the opening decade of the twentieth century, public opinion on Gordon remained polarized. In 1899 he was mentioned in a Daily Gleaner competition to name Jamaica's greatest men living or dead. ${ }^{25}$ This was, however, no index of unanimity. On the anniversary of Gordon's execution in October 1902, the editor of the Jamaica Times observed: "To-day is the anniversary of the execution of Mr. G.W. Gordon at Morant Bay. The event awakens memories of a sad and bitter time in Jamaica - a time which many like to

23. Report of a meeting of the Legislative Council, May 2, 1899, Daily Gleaner, May 3, 1899.

24. "Jamaica's Greatest Men," Daily Gleaner, December 23, 1899.

25. Letter by “G.F.J.," March 1, 1900, Daily Gleaner, March 3, 1900. 
leave alone or forget. Perhaps this is best. The division of feeling is naturally still keen in certain quarters. There are many who would erect a monument to Gordon but the idea has not been universally approved." 26 In a series of letters and articles in the Daily Gleaner and the Jamaica Times in 1906 and 1909, R.E. Clarke, G.F. Judah, and Oscar Plummer defended Gordon against the claims of George Solomon (his contemporary), and Louis Lindo who were convinced that he was a conspirator in the 1865 disturbances and a hypocrite. ${ }^{27}$ In an article, "Past and Present" in the Daily Gleaner in October 1906, R.E. Clarke (reflecting Livingstone's influence), presented the standard defense of Gordon:

They say that Gordon had no right to have spoken to the people as he did, and that his speeches were treasonable and tended to incite rebellion against lawful authority. But Gordon, in his place in the House of Assembly, had attempted over and over again to state the grievances of the people and to obtain some redress of their wrongs-for unless the people themselves gave some indication that they felt themselves wronged, how should the Government believe the statements of their Representative in the Assembly? ${ }^{28}$

In 1912 Claude McKay portrayed Gordon as a hero in a prize-winning poem, "George William Gordon to the Oppressed Natives," in a competition for a patriotic poem organized by the British newspaper, the Weekly. ${ }^{29}$

McKay's poem was not a marker of the widespread acceptance of Gordon as a Jamaican patriot, for he continued to divide opinion in the interwar years. In 1921, for example, W. Clarke MacCalla, in a letter to the Daily Gleaner observed that Gordon had lived before his time: "If the present elected members had lived in Gordon's day, they would all of them have been hanged by the neck for the outspoken criticisms of the Executive and the Government as they now do." He went on to suggest that a statue should be erected by the people, in Kingston, "to the memory of George William Gordon, who gave his life as a martyr in the cause of Truth against oppression and wrong." 30 There were, however, others who continued to see Governor Eyre as the true hero. John M. Lynch, who was a boy of seven at the time of the Morant Bay

26. "Anniversaries," Daily Gleaner, October 23, 1902.

27. See, for example, letter by R.E. Clarke, dated November 26, 1906, Jamaica Times, December 6, 1906; letter by “G.F.J.," dated December 4, 1906, Jamaica Times, December 6, 1906; Oscar Plummer, “A Page from Jamaica History,” Jamaica Times, May 22, 1909.

28. Daily Gleaner, October 16, 1906.

29. See "Claude McKay," Daily Gleaner, May 3, 1912.

30. Letter by W. Clarke MacCalla, dated September 1, 1921, Daily Gleaner, September $5,1921$. 
Rebellion, commented in 1925: "He [Eyre] was a brave English gentleman and a hero. The methods he used to suppress the rebellion in Jamaica of 1865 were not extraordinarily severe." 31 In some quarters, the view that Gordon brought on the 1865 disturbances by his intemperate speech persisted. As H.G. de Lisser noted in 1924:

\begin{abstract}
Even without Gordon the situation would have been serious; with Gordon it became dangerous. But he went blindly on, talking, talking, talking, and forgetting that he had an ignorant and illiterate audience. The explosion came, it was repressed with extraordinary severity. Gordon was hanged. His trial was a farce, it was in every way illegal. Yet Gordon was morally responsible for the death of many human beings, and if he had been given the fair trial he ought to have had he still would have been sentenced to death. ${ }^{32}$
\end{abstract}

De Lisser's view of Gordon was shared by the black legislator, D.T. Wint, who warned in 1930 against "the noxious doctrines" which he accused Marcus Garvey of disseminating: "Remember the Morant Bay Rebellion. Gordon and Paul Bogle did not preach sedition to the people: did not tell them to rebel, but they laid the train for the outbreak, by sowing the seeds of unrest and discord among the people. And I tell you that this is being done again to-day, and unless we are careful we are heading for disaster." 33

Lord Oliver's revisionist study, The Myth of Governor Eyre, published in 1933, did not immediately dispel the notion that Gordon was partly responsible for the rebellion (see also Carnegie 1973:153). Oliver had effectively dismissed the claim that Eyre was a hero, established Gordon's innocence, and demonstrated that social, economic, and political conditions were the underlying causes of the disturbances. Although de Lisser accepted Oliver's findings, he maintained that Gordon precipitated the rebellion: "Of course we ourselves have no doubt that Gordon himself was a bitter, personal, vituperative man, and we have always felt that he should have realised that he was storing up trouble which might end in disaster." ${ }^{4}$ In 1935, a news item from the Daily Gleaner announced a lecture by Colonel Rowe of the Accompong Town Maroons which promised to discuss "What Maroons of Accompong Town did to save Jamaica from Paul Bogle and John [sic] Wm. Gordon in 1865." 35 K.M. Rowley in an article on "The Tragedy of 1865," written in the wake of the 1938 islandwide

31. Letter by John M. Lynch, February 21, 1925, Daily Gleaner, February 24, 1925.

32. See editorial "What is the Cause?" Daily Gleaner, April 4, 1924. The idea of Gordon as a demagogue persisted into the 1950s; see Hall 1959:252.

33. See "Mr. Wint Replies to Attacks," Daily Gleaner, January 17, 1930.

34. See editorial, "Eyre and Olivier," Daily Gleaner, December 14, 1933.

35. See "Lecture which Col. Rowe Maroons' Chief, Will Give in City," Daily Gleaner, June 10, 1935. 
disturbances, reverted to the earliest ideas about Gordon's role in the Morant Bay Rebellion: "He urged his countrymen to undertake an attempt upon law and order, which he alone among the rebels, on account of his superior education and wider experience should have seen to be impossible, impracticable, and disastrous. Upon his head, rather than upon that of Governor Eyre, be the blood of the four hundred or more victims of the rebellion." 36

In the interwar years, when the growth of nationalism prompted a demand for Jamaican rather than British heroes, Gordon was seldom mentioned in the discussions. In fact, H.G. de Lisser suggested in 1938 that one of the reasons for the survival of Gordon and Paul Bogle in the collective memory was the fact that they had been hanged: "I have always known that, if any political leader is to be remembered in Jamaica even before he dies, to say nothing of after he dies, he must get hanged like Paul Bogle and George William Gordon." 37 Since the late nineteenth century, the individuals most often discussed as worthy of veneration were the free Coloreds, Edward Jordon and Robert Osbourn, who were associated with the free-Colored campaign for civil rights in the early 1800s. The appeal of these men for the brown middle classes was that "The free coloured population agitated for equal political rights, but did not resort to arms." 38

The public recognition of Gordon as a patriot came with the introduction of universal adult suffrage in 1944 and the beginning of mass politics which followed on the labor disturbances in 1938. As Eric Williams (1942:91) perceptively observed in 1942, "The events of the years 1935-1938 mark a revolution in the history of the British Caribbean islands. The initiative passed from the brown middle class to the black working class." 39 In 1946 W.A. Bustamante, the near-white leader of the Jamaica Labour Party (JLP), anxious to enhance his leadership credentials among the rural laboring classes, invoked Gordon's memory to provide himself with political legitimacy. It can be argued that he hoped to demonstrate that there was a precedent for a "brown man" with a sincere interest in improving the conditions of the black majority. The link between Bustamante and Gordon was made in an advertisement for a by-election in the parish of Hanover for which W.M. Dickson was the JLP candidate:

36. K.M. Rowley, “The Tragedy of 1865,” Daily Gleaner, April 29, 1939.

37. See "Random Jottings: As I See the World," Daily Gleaner, October 8, 1938.

38. For early references to Edward Jordon, Robert Osbourn, and Richard Hill as great Jamaicans see "Jamaica's Greatest Men," Daily Gleaner, December 23, 1899; "A Famous Jamaican," Jamaica Times, June 22, 1901; "Westwood High School," Jamaica Times, July 22, 1905. See editorial, "Emphasis," Daily Gleaner, September 1, 1944.

39. Williams 1942:91. H.G. de Lisser, the voice of Jamaican conservatism, had in 1933, before the disturbances, observed, "This, too, is the day of the common people, to-morrow it will be still more their day." See the editorial, "The Common People," Daily Gleaner, December 22, 1933. 
When you vote for Dickson you vote for the Jamaica Labour Party, led by Jamaica's Labour and Political Leader, Alexander Bustamante, the man who has done more good and has made more sacrifices for the people of this Country than any other man except George William Gordon who made the supreme sacrifice during the regime of Governor Eyre. Gordon lost his life fighting for the people of his country. Bustamante lost his freedom more than once fighting for you - for your and his country. Deny this if you can. ${ }^{40}$

In the following year, Bustamante initiated a process of valorization involving Gordon, Bogle, and the Morant Bay Rebellion, which he associated with self-sacrifice and patriotism. In a rambling speech urging self-government and constitutional advancement, he linked individuals and events in a narrative of struggle and self-sacrifice which stretched from slavery to the contemporary period:

\begin{abstract}
it is not just today or yesterday or since I have been back to this island that there has been a fight, a literary [sic] fight for freedom. This matter of freedom started from the time of slave days ... Then we must not forget that the fight continued for freedom in 1865, when that great man George William Gordon, a coloured man, who did not fight for himself but for others - for Gordon had no reason to fight for himself; Gordon was somewhat of a wealthy man; Gordon did not have the will to fight for freedom or for himself but he had the will to fight for others.
\end{abstract}

Bustamante treated Gordon and Bogle as coequals in this narrative: "We must not allow the sufferings and pain of death of Gordon and Paul Bogle to go in vain. I would like to emphasize that. We must not allow the pain, the mental and physical pain of George William Gordon and Paul Bogle to go in vain. Those men fought in 1865 . What did they gain? Nothing. They lost their lives." ${ }^{41}$ In establishing the link between the 1865 Rebellion and the Jamaica of representative government, Bustamante anticipated the focus of Vic Reid's 1949 novel, New Day. It was, however, Reid who brought 1865 and its principal historical figures to wider public awareness. Writing in 1965, the theater critic Norman Rae observed: "One may speculate where the source lies of this modern fleet of Gordon-Bogle revival and worship. Did our grandparents know very much about them or hold them in esteem? Taking a long guess, one might put it down to the power of the literary word. It may not be true but it is very likely that Vic Reid's 'New Day' ... put the steam in the Morant Bay train." 42

40. See "Facts for Hanover Voters," Daily Gleaner, November 2, 1946. For a discussion of Bustamante's early career in electoral politics see Eaton 1975.

41. Report of the meeting of the House of Representatives, dated July 9, 1947, Daily Gleaner, July 10, 1947.

42. Norman Rae, “The 1865 Story,” Daily Gleaner, October 22, 1965. 
An indicator of Gordon's elevation in public esteem was the frequency with which he was mentioned as a great Jamaican during the 1950s, at a high point of nationalist feeling. In 1951, for example, W. Adolphe Roberts, the white Jamaican historian and pioneer of the movement for political selfdetermination published Six Great Jamaicans: Biographical Sketches in which Gordon was described as "the misunderstood nationalist and defender of the submerged masses." Roberts went on to point out that there was "no reason whatsoever to think that he incited Bogle to resort to bloodshed." This was a reversal of opinion, for in 1933 he had written of the Morant Bay Rebellion: "The leaders, including an eccentric but slightly guilty colored politician named George William Gordon, were executed wholesale" (Roberts 1933:295). The change the coming of mass politics had made on Roberts's perception of historical figures was demonstrated in his comments comparing the political records of Edward Jordon and Gordon: "He [Gordon] entered politics as a member of the Town Party, but with the difference that Gordon was most passionately the advocate of the poverty-stricken Negro peasants, whereas Jordon and others of the party spoke primarily for the coloured middle-class" (Roberts 1951:2). The transformation of Gordon from traitor to patriot was also reflected in these comments which appeared in a series of short biographies of Jamaican patriots in the Spotlight magazine in 1952: "No statue stands to the memory of this native son who was branded a traitor by British biographers. In the new light which has dawned on his countrymen a century after his murder, his name emerges more gloriously illumined than any other on the sketchy pages of history. He was, by every honest assessment, Jamaica's greatest patriot" (Roberts 1951:29). ${ }^{43}$

Throughout the 1950s, members of the House of Representatives and the Kingston and St. Andrew Parish Council discussed the idea of honoring men, like Gordon and Marcus Garvey, who had been identified as great Jamaicans (Johnson 2004:9). It was not, however, until 1960 (after Jamaica had advanced to full self-government with responsibility for internal affairs) that the proposal to honor Gordon took concrete form in the decision to name the new building that would house the island's legislature after him. At this point, the emphasis was placed on Gordon's career as a parliamentarian. What had earlier been regarded as demagoguery was then perceived as an impassioned advocacy of the interests of the laboring classes. As an editorial in the Daily Gleaner in June 1960 pointed out:

From his seat in that House and from platforms elsewhere in the country, he became a passionate and brilliant spokesman for justice for the people of Jamaica of all classes and estate. He was hanged by Governor John Eyre as a "tyrant" but his name lives on today in the minds of Jamaicans as that

43. See “George William Gordon,” Spotlight, 13, nos. 4 \& 5 (April-May 1952). 
of a devoted patriot and a fanatical supporter of the liberties and social justice which are the bases of free Parliament itself. ${ }^{44}$

Governor Sir Kenneth Blackburn completed Gordon's rehabilitation when he acknowledged his innocence in his address at the opening of Gordon House ninety-five years after his hanging: "It is as a humanitarian that he will be remembered - rash; perhaps - but always urging peaceful means in his efforts to improve conditions for the poor and needy." 45

In 1961, the House of Representatives unanimously approved a motion requesting the government to erect statues of "the illustrious George William Gordon patriot and hero" and Paul Bogle. The debate on the motion is important, for members of the House emphasized that it was only by such measures and teaching about the country's historical development that a strong feeling of national pride could be engendered. ${ }^{46}$ By naming Marcus Garvey a national hero in 1964, followed by Gordon and Bogle in 1965, on the centenary of the rebellion, the government of independent Jamaica began a process of constructing a national identity through the use of "state-induced history" (Zimmer 2003:2). ${ }^{47}$ Members of the government were especially aware that race, color, and class particularism persisted and were intent on achieving a national cohesiveness. Gordon's role in this project of political education was fixed as early as 1961 when he came to symbolize cooperation between Jamaica's Browns and Blacks. In that year Keble Munn, then Minister of Agriculture and Lands and a descendant of Gordon's sister, reminded members of the House that Bogle and Gordon represented two different types of Jamaicans:

\footnotetext{
both playing their part in the struggle to better the lot of the Jamaican masses. This was an important point to bear in mind at a time when there were people in the island who were saying that Jamaicans should be divided one from another. It was significant therefore to bear in mind that while Bogle was a coal black Jamaican, Gordon was a mulatto, the both of them nevertheless working together - and this was 100 years - to build up their country. ${ }^{48}$
}

Four years later at the ceremonies commemorating the 1865 rebellion, Munn explained the significance of the events of 1865 to those persons who claimed ignorance of their importance: "They do not understand that

44. See editorial "George William Gordon," Daily Gleaner, June 2, 1960.

45. See "Gordon House Bar to Dictatorship," Daily Gleaner, October 27, 1960.

46. See "Govt. to Erect Statues of Bogle, William Gordon," Daily Gleaner, July 27, 1961

47. For an extended discussion of the creation of National Heroes in Jamaica see Johnson 2004.

48. See "Govt. to Erect Statues of Bogle, William Gordon," Daily Gleaner, July 27, 1961. 
Bogle and Gordon, one black, one brown were the forerunners of the motto enshrined in our constitution: Out of Many One People." 49

Gordon's symbolic role has remained essentially the same since 1961 but aspects of the historical record have been emphasized to reflect the changing objectives of successive administrations and altered social contexts. During the period of the People National Party's experiment with democratic socialism, Prime Minister Michael Manley described Gordon as "a martyr to social justice." ${ }^{50}$ Under the JLP administration of Edward Seaga, with the restoration of free enterprise and the further entrenchment of a brown business elite in the corporate sector, Gordon was portrayed as a man whose social and economic position brought obligations to the poor which he chose not to ignore. These were the implications of a speech delivered by Carey Robinson, the executive director of the Jamaica National Heritage Trust, to the monthly luncheon of the Rotary Club of Kingston in which he described the historic journey of most Jamaicans as one of self-fulfillment: "the real history and heritage of this country is the journey of its vast majority from the confines of a house of bondage, through desert places, wilderness and valleys of the shadow, towards the promised land of freedom, self-respect and self-realization." The Gordon described by Robinson fitted in with this new ideological landscape: "The great significance of George William Gordon to Jamaica's heritage was that, as a 'well-to-do-man,' he put aside every temptation to take the easy path to social distinction by ignoring the people and instead threw himself recklessly into the fight for human and civil rights." ${ }^{51}$ With the triumph of free market ideology, Gordon began a new career, shilling for the Jamaica Mutual Life Assurance Society which he had helped to found. As an advertisement for the organization in February 1984 stated, "Co-founded in 1844 by our National Hero George William Gordon, Mutual has played an important role in the growth and development of Jamaica." 52

The sustained attempt to project Gordon as the symbol of cooperation between Browns and Blacks, in a society divided along race, class, and color lines, was greeted with skepticism in some quarters. As early as 1962, the "Political Reporter" writing in the Sunday Gleaner in August of that year remarked,

49. See "Enshrinement of 1865 Heroes - Bogle, Gordon Extolled," Daily Gleaner, October 26, 1965.

50. "Charles Sq. Renamed for Sam Sharpe," Daily Gleaner, October 21, 1975.

51. See "Carey Robinson on Our Real History and Heritage," Daily Gleaner, October 18, 1986. For an excellent discussion of this period of Jamaica's recent past see Robotham 2000.

52. See advertisement, Daily Gleaner, February 9, 1984. 
I have been asked why I find no reason to adulate George William Gordon and to declare him a national patriot ... From my own point of view I have read the record and I find George William Gordon a pusillanimous person who blundered into a hanging and I find it difficult to believe that a man who at that time and era married an English wife could have much sympathy with the mass of the Jamaican people. ${ }^{53}$

In 1965, the "Political Reporter" claimed, at the time of the ceremonies commemorating the 1865 rebellion, that Bogle's central role had been downplayed "in order to bolster the national image of the coloured middle class through George William Gordon" (Johnson 2004:11). By 1987, Gordon had suffered a reputational decline. In June of that year a poll conducted by Carl Stone found Gordon to be the most poorly rated of the National Heroes with a 1 percent support among those polled. It is clear that Gordon's association with the idea of cooperation between Browns and Blacks had little relevance in a society where the gap between brown affluence and black poverty had widened. By contrast, Marcus Garvey with his message of black upliftment had broad appeal. ${ }^{54}$ In October 2004, Valerie Dixon, writing in the Sunday Gleaner, expressed incredulity that a rich brown man like Gordon would want to take action to ameliorate the conditions of the poor black laboring classes: "It was never made clear to me how a rich brown man and a poor black man came to share the gallows at the Courthouse in 1865." 55

53. "The Politics of Independence," Sunday Gleaner, August 19, 1962.

54. See "Garvey Seen as Most Outstanding of Our National Heroes," Daily Gleaner, July 8, 1987. Carl Stone had commented on the findings of this poll: "The change [from a previous poll in 1983] has been most likely due to the heavy profile being given to Garvey as part of the Independence Anniversary Celebrations and also to the fact that his black upliftment appeals cut across partisan leanings." The phrase "reputational decline" is Barry Schwartz's (1991:225).

55. See "Paul Bogle and George William Gordon - Heroes or Idiots?" Sunday Gleaner, October 17, 2004. Noelle Chutkan, historian of the Morant Bay Rebellion, had incisively analyzed the condition of the Jamaican working classes 130 years after the disturbances: "It is doubtful that 130 years after the war, an outbreak of hostilities, similar to that of 1865 could occur. Not because people are better off. Far from it. In many ways the poor are poorer. The quality of life is no better as poor people struggle with the barbarity that passes for public transportation, the low level of wages that bear no relationship to the cost of living; the poor roads and uncertain water supply that prevent our farmers from getting their produce to market or their children to school. The administration of justice although now in the hands of paid professionals and not dispensed by partisan interests, is comparatively more expensive and unattainable by the poor than it was in 1865." See Noelle Chutkan, "War is at My Black Skin: Suppression of a Rebellion," Sunday Gleaner, October 15, 1995. 
Gordon's continued reputational decline, in the years after 1992, is best explained by a new emphasis on black nationalism in the successive PNP administrations of Prime Minister P.J. Patterson. This was one aspect of a process which Don Robotham has described as "blackening the Jamaican nation" (Robotham 2000). In 1992, Patterson became the first elected black prime minister and subsequently, as Deborah Thomas has cogently argued, "issued subtle but significant public challenges to the ideology of creole multiracial nationalism." In a series of symbolic gestures, including invitations to African heads of state to visit Jamaica for independence and other celebrations, and an economic policy which sought to entrench a black bourgeoisie as a governing elite, Patterson reinforced the idea that Jamaica is a black country for which Blacks should provide the leadership (Thomas 2004:1112, 83-84). The PNP's adoption of Black nationalism (which had broad appeal among Black Jamaicans across class and gender lines) was partly responsible for its victory in the 1997 general election for an unprecedented third successive term (Thomas 2004:83, 90). The party's black nationalist thrust also provided popular support for its program of displacing the traditional brown economic elite from its accustomed position of dominance (Robotham 2000:13-16).

These developments had implications for the way in which Gordon came to be regarded. Gordon, as Keble Munn's comments, cited earlier, indicated, belonged to an earlier vision of Jamaica as a model of multiracial harmony which had inspired the national motto of the independent nation - "Out of Many, One People." As I have argued elsewhere, the governing elites since the 1950s had advocated a nonracial national identity (inclusive of all racial groups), rejecting the black racial counteridentity of the island's majority as advanced by Marcus Garvey (Johnson 1998:128-30). During Patterson's tenure in office, marked by a "more explicitly racialized concept of citizenship," Gordon became increasingly irrelevant as a symbol of national identity. In 1997 the reinstatement of Emancipation Day as a public holiday reflected the emphasis placed on African cultural heritage as an essential element in promoting a sense of national identity (Robotham 2000:16; Thomas 2004:12, 158).

The life and political career of George William Gordon became a source of competing narratives from the time of his execution in October 1865. These contested memories reflected the color and class divisions within Jamaican society and the divergent perspectives on the position of the black majority in the political sphere. The decisive shift in the perception of Gordon from traitor to patriot came only with the emergence of mass politics when he emerged, in public discourse, as a defender of the interests of the black laboring classes. After independence, successive governments (led in both parties by members of a brown elite) appropriated Gordon as a symbol of collaboration between Browns and Blacks in establishing a pantheon of national heroes. By the 1980s, however, Gordon went into reputa- 
tional decline as contemporary developments, specifically the deteriorating social and economic conditions of the black majority, indicated the limits of the potential for mutually beneficial cooperation across the color line. This decline has continued to the present day as Jamaicans increasingly assert their black identity.

\section{REFERENCES}

AUGIER, ROY, 1966. Before and After 1865. New World Quarterly 2:21-40.

CARnegie, James, 1973. Some Aspects of Jamaica's Politics: 1918-1938. Kingston: Institute of Jamaica.

CUNDALL, FRANK, 1915. Historic Jamaica. London: Institute of Jamaica.

EATON, GEORGE E., 1975. Alexander Bustamante and Modern Jamaica. Kingston: Kingston Publishers.

Fletcher, DunCAN, 1867. Personal Recollections of the Honourable George $W$. Gordon, Late of Jamaica. London: Elliot Stock.

FyFe, LAURENCE R. \& A.C. SinclaiR, 1883. Outlines of the History of Jamaica. In The Handbook of Jamaica Comprising Historical, Statistical and General Information Concerning the Island. Kingston: Government Printing Establishment.

GARDNER, W.J., 1873. A History of Jamaica from its Discovery by Christopher Columbus to the Year 1872. London: Frank Cass, reprint.

Green, William A., 1976. British Slave Emancipation: The Sugar Colonies and the Great Experiment 1830-1865. Oxford: Clarendon Press.

HaLl, Douglas, 1959. Free Jamaica 1838-1865: An Economic History. New Haven: Yale University Press.

HART, ANSELL, 1972. The Life of George William Gordon. Kingston: Institute of Jamaica. Higman, B.W., 1999. Writing West Indian Histories. London: Macmillan.

Holt, Thomas C., 1992. The Problem of Freedom: Race, Labor, and Politics in Jamaica and Britain, 1832-1938. Baltimore: Johns Hopkins University Press.

JACOBS, H.P., 1973. Sixty Years of Change, 1806-1866: Progress and Reaction in Kingston and the Countryside. Kingston: Institute of Jamaica.

JOHNSON, HOWARD, 1998. The "Jamaica 300" Celebrations of 1955: Commemoration in a Colonial Polity. In Peter Burroughs \& A. J. Stockwell (eds.), Managing the Business of Empire: Essays in Honour of David Fieldhouse. London: Frank Cass, pp. 120-37.

-, 1999. The Historiography of Jamaica. In B.W. Higman (ed.), General History of the Caribbean, Vol. 6, Methodology and Historiography of the Caribbean. London: UNESCO/Macmillan, pp. 478-530. 
-, 2004. The Politics of the Past: National Heroes in Post-Colonial Jamaica. Mona: Department of History, University of the West Indies.

Lisser, H.G. DE, 1913. Twentieth Century Jamaica. Kingston: The Jamaica Times.

—, 1919. Revenge: A Tale of Old Jamaica. Kingston: Gleaner Press.

LUMSDEN, JOY, 1998. A Forgotten Generation: Black Politicians in Jamaica, 1884-1914. In Brian Moore \& Swithin Wilmot (eds.), Before and After 1865: Education, Politics and Regionalism in the Caribbean. Kingston: Ian Randle, pp. 112-22.

ROBERTS, W. ADOLPHE, 1933. Sir Henry Morgan: Buccaneer and Governor. New York: Covici, Friede.

—, 1951. Six Great Jamaicans: Biographical Sketches. Kingston: Pioneer Press.

Roвотнам, Don, 2000. Blackening the Jamaican Nation: The Travels of a Black Bourgeoisie in a Globalized World. Identities 7:1-37.

SCHWARTZ, BARRY, 1991. Social Change and Collective Memory: The Democratization of George Washington. American Sociological Review 56:221-36.

SEMMEL, BERNARD, 1962. The Governor Eyre Controversy. London: MacGibbon and Kee.

ThOMAS, DeBORAH A., 2004. Modern Blackness: Nationalism, Globalization, and the Politics of Culture in Jamaica. Durham NC: Duke University Press.

WALVIn, JAMES, 1994. The Life and Times of Henry Clarke of Jamaica, 1827-1907. Ilford, U.K.: Frank Cass.

WILL, H. A., 1970. Constitutional Change in the British West Indies 1880-1903. Oxford: Clarendon Press.

WILlIAMS, ERIC, 1942. The Negro in the Caribbean. Washington DC: The Associates in Negro Folk Education.

ZIMMer, OLIVER, 2003. A Contested Nation: History, Memory and Nationalism in Switzerland, 1761-1891. Cambridge: Cambridge University Press.

\section{HOWARD JOHNSON}

History and Black American Studies

University of Delaware

Newark DE 19716, U.S.A.

$<$ howardj@udel.edu> 